\title{
THE INFLUENCE OF MARGIN MURABAHA RECOGNITION METHOTD ON ISLAMIC BANKING SUSTAINABILITY
}

\author{
Fithrah Kamaliyah \\ Pamulang University \\ fkamaliyah@gmail.com
}

\begin{abstract}
The purpose of this study was to analyze the two method of margin murabaha recognition in Indonesian Islamic banking, they are proportional and annuity. How they effect business sustainability expressed by level of risks and the soundness of Islamic banks. The object of research is Bank Muamalat Indonesia according to its Annual Financial Statements in period 2001-2014. This research using SEM analysis to see the influence of both methods. The result of this study, suggesting that proportional method has 45\% influence on the level of risk and 23\% of the bank's soundness. The annuity method has $51 \%$ on the level of risk and $57 \%$ of the bank's soundness negatively.
\end{abstract}

Keywords: Margin murabaha method, the bank's risks, the soundness of Islamic banks.

\section{INTRODUCTION}

Indonesia as the largest Muslim population in the world (BPS, 2010), since 1992 the dual banking system has established due to fulfill the demand of community who need the alternative of banking services according to sharia principles. Nevertheless, it also give certain challenges for the development process of Islamic bank itself whereas conventional banking as the opposite side in gaining customers. Hence, the Islamic bank has an obligatory to maintain good performance in order to survive in financial industry and also be able to manage the level of risks efficiently.

According to Marston and Sundararajan (2006: 94), bank's management need create a variety products and services which making favorable prospect with regard Asset Liability Management (ALMA), by considering and managing risks to the achievement of expected profitability.

Financial Services Authority (OJK) has conducted studies to look at the soundness of Islamic bank in March 2018, as shown in table 1 below:

Table 1. Measuring The Level of Soundness of Islamic Bank, 2018

\begin{tabular}{|l|l|l|}
\hline \multicolumn{1}{|c}{ Indicator } & \multicolumn{1}{c|}{2017} & March2018 \\
\hline $\begin{array}{l}\text { CAR (\%) } \\
\text { Quality of Fixed Assets }\end{array}$ & 17,91 & 18,47 \\
Profitability: & 4,22 & 4,21 \\
- NOM (\%) & 0,67 & 1,40 \\
$-\quad$ ROA (\%) & 0,63 & 1,23 \\
\hline
\end{tabular}




\begin{tabular}{|c|l|l|}
\hline$-\quad \begin{array}{l}\text { BOPO (\%) } \\
\text { Liquidity: }\end{array}$ & 94,91 & 89,90 \\
- STM (\%) & 29,75 & 29,63 \\
$-\quad$ FDR (\%) & 79,65 & 77,63 \\
\hline
\end{tabular}

Based on the table above, the growth of Islamic bank has increased both in terms of capital adequacy, the quality of fixed assets, operating income and short-term liquidity. However, reduced of profitability indicated by ROA $1,23 \%$, indicating that the profit earned from the asset is unstable, and need more strategies for making efficiency to gain profits. In addition, the ratio BOPO which $89.90 \%$ showed the level of efficiency of sharia bank not good enough, but this should still be minimized the cost to gain a higher profit. FDR ratio also needs to be maintained for avoiding liquidity risk.

Islamic banking weaknesses in terms of profitability, efficiency and liquidity may caused by several factors. One major problem faced by Islamic bank is their management still use patterns of conventional bank management (Hanif, 2011: 166-175). Determining of margin, fee and nisbah (ratio) still use interest rate as an indicator of comparison for management of Islamic bank in making economic decisions. The application of the annuity method as an Islamic Accounting Standards which follow conventional methods of calculating profit margin in murabaha (cost-plus financing).

Annuity method has endorsed by MUI's fatwa No. 84/ DSNMUI/XII/2012 on tamwil bi almurabaha, with the aim of maintaining the stability of the soundness of Islamic bank. Based on the fatwa, the Islamic banks are currently allowed to choose either the proportional or annuity methods to calculate margin of murabaha with regard of urf (tradition) in the Islamic bank. Annuity method which is one of the concepts developed by conventional economics has a basic principle of "time value of money" is contrary to the concept of Islam that promotes the principle of "economic value of time" (Supriyanto, 2014: 231).

In the context of Indonesia, the practical of these methods is still debatable at the level of authority. The regulation of Bank Indonesia No. 9/634/DPbS April 20, 2007 oblige the Islamic bank to use the proportional method, while, the FSA provides an option for the bank to use either proportional of effective method. It indicates that the FSA is still not has a clear concept of margin in the Islamic financial system which is supposed to has its own character.The use of annuity method in Islamic bank financing products should not be allowed. In fact, the imposition of a large margin in initial financing and declining steadily until the end, philosophically, it creates exploitative to the borrowers. Eventually, the goal of achieving justice and economic prosperity can not be realized (Supriyanto, 2014: 16).

\section{LITERATURE REVIEW}

Annuity method in more detail defined as a series of payments in the same amount and predetermined period (Horne and Wachowicz, 2005: 18). Based on conventional literature, the time of payment in annuity method is divided into two. Firstly, ordinary / deffered annuity is the payment made on the end of each period. Secondly, annuity due is made at the beginning of each period (Peirson, 2002: 65-66).

The difference between the proportional and the annuity mehods in the case of the acquisition of margin. It 
can be seen through the following curves;

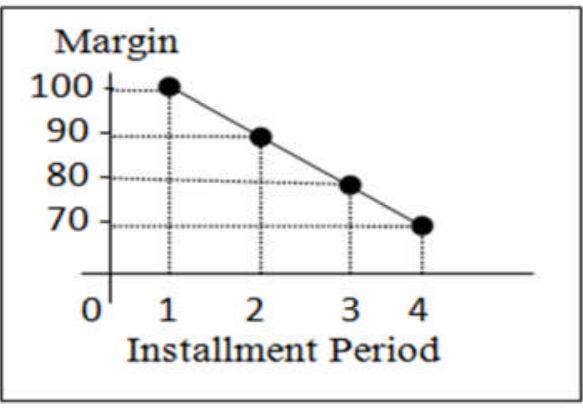

Figure 1: Annuity Margin Curve

The calculations using annuity method is basically refers to concept of time value of money. Brigham and Ehrhardt (2002: 286) said "a dollar in hand today is worth more than a dollar to be received in the future, because if you had it now, you could invest it, earn interest, and end up with more than one dollar in the future". Base on the statement, it is explained that the purpose of the annuity method is to use the money that is currently available to invest, earn interest and short-term needs.

Related research to revenue recognition methods in murabaha in particular through the implementation of an annuity and a proportional method has not been done. Adnan (1996: 241) said regarding the accounting concepts and practices in Bank of Malaysia Berhad (BIMB) and Bank Muamalat Indonesia (BMI). This research focuses on the investigation and evaluation concept of accounting was adopted. Finding of this research are BIMB using Sum of Digit (SOD) as the calculation of the profit in murabaha financing which resemble annuity and also Constant Rate of Return (CRR) method. By comparing rate of profit to the cost incurred by the bank, the result is the percentage of profit that uses CRR recognized fairer because it has same

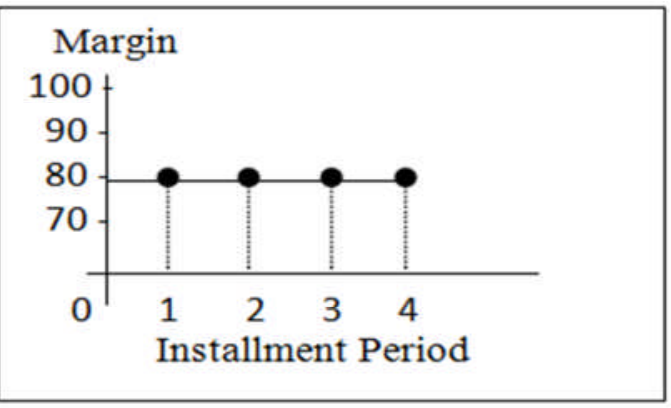

Figure 2: Proportional Margin Curve application rate of profit in Islamic bank both macro and micro levels. Data collection used the documentation and survey in Bank Syairah Mandiri and Bank Dananmon Syariah by looking at financial statements and the distribution of profit sharing. The results of this study indicate that proportional method is an appropriate method with Islamic principles are based on the economic value of time, it is because Islamic bank do not identify any installment of principal or margin. In practically, the customers oblige pay for the remainder payable without even distinguish between the principal and margin. In the annuity method, revenue trends over time decreased, therefore, the funds of customer be harmed.

Another research conducted by Rosmiati et.al (2014: 1-15) on a comparative analysis of performance between the two methods of annuity and proportional in murabaha financing agreement. This research is quantitative descriptive using data at Bank Jabar Banten branch Singaparna. Comparison of the performance both methods are measured based on four indicators, namely: 1) Receivables successfully billed/ unbilled, 2) Amount of principal installment, 3) Margins installment and 4) The amount of payment. The results 
of this analysis shows that the annuity method has a good performance at the beginning of the period installment and continue to decline with the declining of margin earned by bank. While the proportional method performance is remain stable from beginning until the end of period

Mukhlisin and Hudaib (2014: 3840), provide conclusions of criticism over recognition methods in murabaha. Their research concluded that the application to the annuity method in Indonesia (which basically adopted The IFRS Standard) in addition incompatible with sharia law, it also creates economic liberalization with their political and economic interests for stakeholders in Islamic financial institutions and the demand from especially gaining profitability.

Regardless of the pros and cons of this new policy, the adoption of IAS converging towards IFRS in 2012 and the establishment of PAPSI 2013 will remain continue. It is an impact on the presentation, measurement and financial reporting of Islamic bank. As a supporter of implementing the income calculation of those methods, Ikatan Akuntan Indonesia (IAI) published Technical Bulletin 9 in 2013. It contains a technical reference for each method of revenue recognition. It also explained that the accounting for annuity should be reffered to IAS 50, IAS 55 andIAS 60 on financial instrument, whereas IAS 102 does not specifically regulate the method. Eventually, IAS 102 was publised in 2013 to accomodate this method.
Thus, it can be seen that the emergence of fatwa regarding on the permissibility of the annuity method is derived from IMF in particular of international political economy that require the members to adopt same system which must come from conventional concept and value of liberalism.

\section{RESEARCH METHOD}

The sample used in this study is the annual financial report of Bank Muamalat Indonesia (BMI) in 20012014 period which was then divided into two, namely proportional period in 2001-2007 and annuity period in 20082014. This study used quantitative and qualitative analyses. The analysis of the influence of margin both methods to the risks and soundness of Islamic banks is done using Structural Equation Model (SEM) by AMOS 21. The indicators from this research in assessing the risks of credit are NPF, FDR and Operating Efficiency Ratio (BOPO). Meanwhile, the soundness of banks measured by ROA, ROE, NIM and CAR.

\section{RESULTS AND DISCUSSION}

Before exposing the influence of proportional and annuity margins, the researchers gave a description of the comparison level of risks and soundness during the period of using both methods as shown in table below:

Table 2. Comparison Level of Risk and Soundness during Proportional and Annuity Period

\begin{tabular}{|c|c|c|c|}
\hline Indicator & $\begin{array}{c}\text { Proportional } \\
\text { Period }\end{array}$ & Annuity Period & Notes \\
\hline$\%$ NPF & 4,11 & 4,19 & Annuity 0,08\% upper \\
\hline$\%$ FDR & 86,93 & 92,16 & Annuity 5,23\% upper \\
\hline$\%$ BOPO & 85,80 & 89,06 & Annuity 3,26\% upper \\
\hline
\end{tabular}




\begin{tabular}{|c|c|c|l|}
\hline Indicator & $\begin{array}{c}\text { Proportional } \\
\text { Period }\end{array}$ & Annuity Period & \multicolumn{1}{c|}{ Notes } \\
\hline$\%$ ROA & 2,29 & 1,29 & Annuity 1\% lower \\
\hline$\%$ ROE & 20,86 & 20,56 & Annuity 0,3\% lower \\
\hline$\%$ NIM & 6,60 & 5,07 & Annuity 1,53\% lower \\
\hline$\%$ CAR & 12,35 & 13,04 & Annuity 0,69\% upper \\
\hline
\end{tabular}

On average, the application of annuity method has an advantage in terms of Capital Adequacy Ratio (CAR). In annuity method the bank will be able to provide capital reserves that were received large margin at the beginning of the period as a fund to cover the risk of reduction assets due to suffered by banks. Furthermore, the soundness level from both methods seem still give a good level. Nevertheless, the difference between the average of each ratios, it appears that the risk level of annuity method has a higher value than proportional method. These calculations of this study have same result to research that conducted by Gunawan (2010: 160), Supriyanto (2014: 231), Amir et.al (2015: 850) and Rosmiati et.al (2014:1-15).

The basic formation of structural equation model above as Sehrish et.al (2011: 62) said, factors may effect the bank's performance are divided into two which are internal and external factors. Major issue in internal may faced commercial banks is the decision of management and policy objectives (Staikouras and Wood, 2004: 2). The application whether proportional or annuity methods is a policy that can be selected based on fatwa tamwil bi al murabaha in purpose due to increasing performance and income of Islamic bank. Beside, in order to create a good environment in Islamic banking industry, it has to be supported with professional management to maintain any risks especially in contract-based financing such as murabaha. As revealed by Mason (1995: 1-5), a good risk management will create efficiency and increase the value of bank in reducing the possibility of fee income and cash flow.

The evidence of proportional and annuity margin's effect to the level of risk and bank's soundness can be viewed the following table:

Table 3: Correlation of Margin's Proportional to Risk Level and Soundness of Islamic Banks

\begin{tabular}{|l|c|c|c|}
\hline \multicolumn{1}{|c|}{ Correlation between Variables } & Estimation & Probability & Notes \\
\hline Margin's Proportional $\rightarrow$ Risk & 0,45 & 0,045 & Significant \\
\hline Risk $\rightarrow$ Soundness of Bank & $-0,34$ & 0,022 & Significant \\
\hline Margin Proportional $\rightarrow$ Soundness of Bank & 0,23 & 0,033 & Significant \\
\hline
\end{tabular}

Correlation between the variable margin proportionate to the risk and the bank soundness has a probability value $<0,05$ so Ho rejected and Ha accepted, meaning that there is a relationship between the application of the proportional method with the risk and soundness in Islamic banks. Based on these results, the use of margin proportional method was positively related to risk of $45 \%$ and a positive relationship to the soundness of the banks 23\%. This positive relationship proportional method on the soundness of the banks indicate that this study are consistent with the findings disclosed by 
Table 4: Results Correlation Margin of Annuity with Risk and Soundness Islamic Bank, processed

\begin{tabular}{|ll|c|c|c|}
\hline \multicolumn{2}{|c|}{ Correlation Between Variables } & Estimation & Probability & Notes \\
\hline Annuity Margin & $\rightarrow$ Risk & 0,51 & 0,005 & Significant \\
\hline Risk & $\rightarrow$ Bank Soundness & $-0,58$ & 0,000 & Significant \\
\hline Annuity Margin & $\rightarrow$ Bank Soundness & $-0,57$ & 0,000 & Significant \\
\hline
\end{tabular}

As margin using the proportional method, margin annuity also has a relationship with risk and soundness of Islamic banks, as indicated by the probability value $<0.05$. Relations margin annuity on the level of bank risk positive $51 \%$ and negative correlation to the soundness of banks $-58 \%$, meaning that the use of margin annuities have a strong enough relationship in increasing the risk and diminishing the soundness of the Islamic bank.

Regarding the impact of the proportional method and annuities to the soundness indicators of banks can be seen in Table 5 below:

Table 5: Impact of Margin Proportional and Annuity on Bank Soundness, processed.

\begin{tabular}{|l|c|c|}
\hline \multicolumn{1}{|r|}{ Method } & Annuity & Proportional \\
\hline Risk and Bank Soundness & & 0,49 \\
\hline FOPO & 0,55 & 0,06 \\
\hline NPF & $-0,13$ & 0,26 \\
\hline ROA & 0,42 & 0,10 \\
\hline ROE & $-0,77$ & 0,43 \\
\hline NIM & $-0,40$ & 0,004 \\
\hline CAR & $-0,70$ & 0,033 \\
\hline
\end{tabular}

The use of the annuity method increases the chances of risk is higher than the proportional method by $55 \%$ and also increased credit risk by $42 \%$. But the annuity method successfully reduced the risk of liquidity $-13 \%$ which lacks the CAR increase of $46 \%$. As annuity margin collected rapidly at the beginning period, it is possible the bank to the backup its capital to cover the risk and pay short-term obligations. Neither the collection of margin early can make the bank more liquid to use financial repeatedly to another financing.
However, the application method of annuities have a bad impact on the growth of bank soundness, because it can decrease of the ROA value $-77 \%$, ROE $-40 \%$ and NIM $-70 \%$. This is due to the acquisition of murabaha margin diminished in the long-term period so the bank's returns will be decrease. The decrease in both the return of assets, equity, and net margin will give the impact of losses for banks, especially in the long term the bank will have difficulty in operating efficiency. The decline in bank profitability in the long term, will also cause investors become 
reluctant to invest their funds. It is especially noticeable in the last three years (2012-2014) of impairment ROA, ROE, and NIM on BMI:

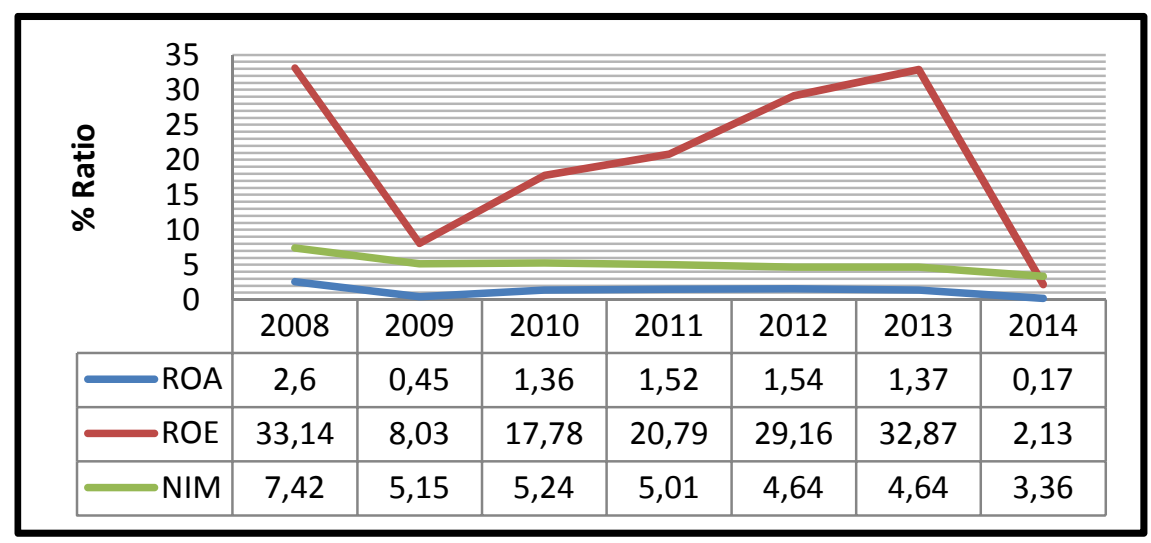

Figure 3: The Comparison between ROA, ROE, and NIM of BM

Meanwhile, the positive side of the application of proportional method is an increase ROE of 43 percent and ROA of 10 percent. Altough, the porportional method is not as good as annuity method in enhancing the value of bank liquidity. However, this method showed increase the value of return in terms of equity and assets gradually.

In this study, the researchers also conducted interview on two pratitioners of Islamic Bank, Rifki Ismal (2017) as the manager of financial market of Bank Indonesia. And Benny Wicaksono (2017) as the former director of Bank Mega Syariah. In his statement, Benny Wicaksono said the use of annuity method is for the sake of liquidity mitigation. He suggests that this method will be able to pay higher yield in the short time of maturity. Since the source of fund of Islamic bank is a short time period while the financing agreement is generally long term period, hence, it would be the risk of liquidity may occur and the bank requires an appropriate method to cover the short term obligations.

It also disclosed in mathematical simulation ever done by Rifki Ismal (2016) that the annuity method reduce business expansion of Islamic bank rathen than propotional method. Regarding to the impact on the soundness of Isalmic bank, this method (annuiy) may gives a better performance in terms of risk mitigation. On the other hand, the loss of the element of fairness, maslaha etc of the annuity method will reduced public trust in Islamic banking institution, hence, it can be geared towards a decrease in quality of bank soundness (the decline of deposit). In his research also disclosed that the goodness of annuity is the achievement of a 5 percent market share of Islamic bank faster.

Based on the results from statistical calculation and interviews, it can be concluded that a positive side of the application of annuity is in terms of liquidity mitigation. It also enhance the competitiveness of Islamic bank againsts other competitors. On the other hand, the threat of reputational risk will occur and affecting decreased customer trust to Islamic bank. Evidence regarding the impact of the application of both methods is axpected to be a consideration for Islamic bank in taking the right decision of the appropriate methods. 


\section{CONCLUSSION}

This study provides some of findings, first, BMI which is sampled in this study, receiving the impact of the application of proportional method and annuities. As data have been processed through SEM analysis, that both methods have a different influence on the risks and bank soundness banks. Both methods still have a chance to increased operational risk and credit, but the annuity method has a higher value, so the annuity method is considered less efficient. However, more annuity method can reduce the risk of liquidity with the acquisition of capital reserves higher than the annuity method. Annuity method also have a negative effect for the reduced levels of profitability looks

\section{REFERENCES}

Adnan, Muhammad Akhyar. (1996). An Investigation of Accounting Concepts and Practices in Islamic Banks The Cases of Bank Islam Malaysia Berhad and Bank Muamalat Indonesia. $\mathrm{PhD}$ Dissertation .Wollongong University. p.241.

Amir et. al. (2015). Criticism of Annuities in Murabaha Transaction: Allowing RibaThrough Fatwa? (A case study of Shariah Banking in Indonesia).Kuala Lumpur International Business, Economics and Law Conference 6(1). 22-26.

An-Nadwy, Ali Ahmad. (1999). Mausu'ah Al-Qowaid wa Dhowabith Al-Fiqhiyah Jilid 2. Dasmaskus : Daarul Alim AlMa'rifah, 60-62. at the total impact of $-77 \%$ ROA, ROE of $-40 \%$ and $-70 \%$ NIM.

Second, the results of the analysis, it can be said one of the motives application of the annuity method today is liquidity motive. This argument has been given to stand the sustainability of Islamic Banking in Indonesia. Banks using this method is to meet short-term obligations. This is due to the source of Islamic bank funding comes from more short-term funds that banks must pay for the results at maturity. Regrettably, however, the application of the annuity method ignores the bank's profitability, resulting in decreased profitability of Islamic banking. The fall of the level of profitability can lead to loss of confidence of investors to invest their funds in Islamic banks.

Brigham, Eugene F. and C. Ehrhardt, Michael. (2002). Financial Management: theory and Practice Tenth Edition. USA: Harcout College Publishers.

Dusuki, Asyraf WajdidanAbozaid, Abdulazeem. (2007). A Critical Appraisal on The Challenges of Realizing Maqashid Al-Shariah in Islamic Banking and Finance: IIUM Journal of Economics and Management 15(2), 151.

Ghazali. (2010). Shifa al-Ghalil in Tawfique Al-Mubarak and Noor Mohmmad Osmani, Aplication of MaqashidShari'ah and Maslahah in Islamic Banking Practices: Journal of Islamic Banking. Qatar: Qatar Foundation. p.5.

Gunawan, Aang. (2010). Analisis Perlakuan Pendapatan Skim 
Murabaha.

Theses

Universitas Trisakti. p.160.

Hanif, Muhammad (2011). Differences and Similarities in Islamic and Conventional Banking: International Journal of Business and Social Science 2(2), 166-175.

Hasan, Mahmud Abdul Karim. (1995). Al-Maslahah

Al-Mursalah.

Beirut: Daar An-Nahdhah AlIslamiyya.

Ismal, Rifki et. al. (2016). Faktor-faktor yang memperngaruhi pembiayaan berbasis bagi hasil (Equity Financing) pada Bank Syariah X. Jurnal Aplikasi Bisnis dan Manajemen. 10.17358/JABM.2.3, 281-290.

Ismal, Rifki. E-mail Interview. (2017). Why annuity method more acceptable by Islamic Banking in Indonesia than proportional method in murabahah margin recognition?. Jakarta.

Wicaksono, Bambang. Whatsapp Interview. (2017). Why annuity method more acceptable by Islamic Banking in Indonesia than proportional method in murabahah margin recognition?. Jakarta.

K., Staikouras C. and E., Wood G. 2004. The determinants of European Bank Profitability International Business \&Economics Research Journal 3(6), 2.

M. Nashrullah K. Galuhand Noor, Hasni. (2014). KonsepMaqashid Al-Syariah dalam Menentukan Hukum Islam. Jurnal Ekonomi Syariah dan Hukum Ekonomi Syariah Al-Iqtishadiyah 1(1),52.
Marston, David and Sundararajan, V. (2006). Unique Risk of Islamic Banks: Implication for Systemic Stability. Jeddah: IRTI.

Mason, S. P. (1995). The Allocation of Risk: Working Paper Harvard Business School. Boston: Harvard Business School.

Mukhlisin and Hudaib. (2014). "Is there a political economy of accounting in financial reporting standardization for the Islamic financial institutions?". $10^{\text {th }}$ International Conference on Islamic Economic and Finance. United Kingdom: University of Glasgow. p.38-40.

Rosmiatiet. al. (2014). "Comparative Analysis Annuity Method and The Mothod of Proportion in Performance Assessment in Financing Transaction on Murabaha". Siliwangi University Journal 157.

Sehrish et. al. (2011). "Factors Affecting Bank Profitability in Pakistan". The Romanian Economic Journal, 62.

Shahruddin, Amir. (2010). Maslahah Mafsadah Approach in Assessing the Shariah Compliance of Islamic Banking Product: International Journal of Business and Social Science Vol.1 No.1. USA: Centre for Promoting Ideas, 132.

Supriyanto, Trisiladi. (2014). Konsep Rate of Profit dalam Perspektif Ekonomi Islam: Disertation SPS UIN Jakarta. Jakarta: Graduated School UIN,231. 